\title{
Identification of river water and groundwater interaction at central part of the Kathmandu valley, Nepal using stable isotope tracers
}

\author{
Ramita Bajracharya $^{\# 1}$, Takashi Nakamura ${ }^{\# 2}$, Bijay Man Shakya ${ }^{\# 3}$, Kei Nishida ${ }^{\# 4}$, Suresh Das \\ Shrestha $^{\# 5}$, Naresh Kazi Tamrakar ${ }^{\# 6}$ \\ \#1 Central Department of Geology (CDG), Tribhuvan University, Nepal, 977-9841843309 and e- \\ mail: bajrarami@yahoo.com \\ \#2 Interdisciplinary Centre for River Basin Environment (ICRE), University of Yamanashi, Japan, \\ e-mail: tnakamura@yamanashi.ac.jp \\ \#3 Interdisciplinary Centre for River Basin Environment (ICRE), University of Yamanashi, Japan, \\ e-mail: g17de002@yamanashi.ac.jp \\ \#4 Interdisciplinary Centre for River Basin Environment (ICRE), University of Yamanashi, Japan, \\ e-mail:nishida@yamanashi.ac.jp \\ \#5 Central Department of Geology (CDG), Tribhuvan University, Nepal, 977-9851084659 and e- \\ mail: suresh@rainwater.org.np \\ \#6 Central Department of Geology (CDG), Tribhuvan University, Nepal, 977-9841208099 and e- \\ mail: nktam777@yahoo.com
}

\section{ABSTRACT}

The groundwater and surface water are two interrelated systems of the water resources and belong to one of the processes of hydrologic cycle. If the interconnectivity between these two systems can be recognized and established for particular rivers, the probable contamination of any one of the systems caused by anthropogenic activities can be indicated and suggested for necessary mitigative measures. Thus, this study was focused on identifying the interconnection of groundwater and river water using hydrogen $(\delta \mathrm{D})$ and oxygen $\left(\delta^{18} \mathrm{O}\right)$ stable isotopes of water. Monthly water samples (June 2010 to March 2011) collected from shallow groundwater and river water were used for this research. The river water samples were collected from the Bagmati River (3 locations), the Bishnumati River (2 locations), the Dhobi Khola (2 locations) and the Manahara River (1 location) whereas some groundwater samples (from 7 locations) were collected from these river corridors $(2$ samples from 35 to $60 \mathrm{~m}$ and 4 samples from 90 to $200 \mathrm{~m}$ from the river channel) and three samples were collected far from the river channel.

The concentration of chemical parameters, especially $\mathrm{Na}^{+}$and $\mathrm{Cl}^{-}$from the river water, was higher in the dry season (Dec-Jan), which decreased to nearly half in the wet season (July-Sep). The values of $\delta^{18} \mathrm{O}$ and $\delta \mathrm{D}$ show significant temporal variation ranging from $-6.4 \%$ to $-9.3 \%$ and $-43.3 \%$ to $64.5 \%$, respectively. The concentration of $\mathrm{Na}^{+}$and $\mathrm{Cl}^{-}$of groundwater varied with the distance from the river channel. Significant temporal variation of stable isotopes and $\mathrm{Na}^{+}$and $\mathrm{Cl}^{-}$was observed in that groundwater which was collected from 35 to $60 \mathrm{~m}$ from river channel whereas constant values were measured in water samples taken from 90 to $200 \mathrm{~m}$. Similarity in isotopic composition of groundwater and river water in dry season conforms the recharge of the river water from nearby groundwater (GW1, GW3 and GW6). Contrarily, GW2 and GW4 (located within 35- $60 \mathrm{~m}$ ) have higher probability of recharge from the river water.

Key words: Stable isotopes, Chemical ions, Groundwater- Surface water, interaction, Kathmandu Valley 


\section{INTRODUCTION}

The groundwater and surface water are two interrelated systems of the water resources. It is one of the processes of hydrologic cycle. The relationship of these two water systems can observe in all landscapes such as pond, lake, and reservoir but is commonly researched at the river reach scale to classify as connected (losing and gaining) and disconnected system. Some of research also focused on the stream to classify as losing-connected and losing-disconnected reach of the river [1]. Different methods had been applied to study about interaction of groundwater and surface water such as direct measurement of water flux, heat tracer methods, environmental tracer methods (isotope and geochemical), solute tracer methods, methods based on Darcy's Law [2] and geophysical methods [3][4][5]. Among these methods, stable environmental isotopes (hydrogen and oxygen) and hydrochemistry are widely applied for such study [6][7][8][9][10][11][12][13][14][15][16][17][18][19].

The interconnection of groundwater and surface water can affect the quantity and quality of both water systems. But in the context of Nepal, such studies has just started in few areas [13]. Earlier studies had only focused on quality of groundwater [20][21][22][23][24][25] as well as of surface water. Previous studies based on quality of groundwater of Kathmandu valley have reported high value of chloride, nitrate and coliform in shallow groundwater. Nitrate level at shallow depth is higher as compared with high depth in urban areas due to anthropogenic sources such as poorly managed septic tanks, sewer pipes and solid waste disposal [26].

Previous researches on river water quality of the Kathmandu valley have reported that the downstream segments which travelled through urban areas has more contaminated than the upstream segments [27][28]. The Bagmati River and its tributaries were classified into distinct zones according to water quality classes as defined by the "extended biotic index". The river segments are classified as heavily polluted to very heavily polluted [29]. Low dissolved oxygen with high coliform is noted in all downstream section of the Bagmati River and its tributaries. This deteriorating quality of river water has caused frequent cases of water borne diseases such as diarrhea, dysentery, cholera, and skin diseases among people living in riverside areas [30].

The earlier research related with interconnection of groundwater and surface water has also indicated that the northern part of the Bagmati river and the Bishnumati river are connected with surrounding groundwater [13]. Concentration of chemical parameters is decreased as the distance from the Bagmati river channel has increased. The higher contamination of groundwater along river banks towards urban river corridor indicate the intrusion of nearby polluted river water [31]. Thus the purpose of this study is to identify connecting condition of groundwater and river water at the central part of the Kathmandu valley. Specific objectives of this study is to 1) investigate spatial and temporal variation of water chemistry and environmental isotope in river water and groundwater and 2) relationship between river water and groundwater along the Bagmati river, the Bishnumati river and the Dhobi khola.

\section{STUDY AREA}

The study area covers major river corridors of central part of the Kathmandu Valley. The valley is extended about $30 \mathrm{~km}$ towards EW direction and $25 \mathrm{~km}$ towards NW covering about $650 \mathrm{~km}^{2}$ areas. The valley is surrounded by the Shivapuri, Chandragiri and Phulchauki mountain range from north, south and west respectively. The Bagmati River is the only one outlet drainage of the valley. The major Bagmati River has many tributaries such as the Bishnumati and the Dhobi Khola flowing from north, the Manahara flowing from northeast, the Hanumante from east, the Godawari and the Kodku from southeast and the Nakhhu from south direction.

The surrounding mountain ranges are composed of sedimentary and metamorphic rock with gneiss and migmatites [32] whereas the valley consist Plio-Pleistocene fluvial, fluvial lacustrine and fluvio-deltaic sediments [33]. The study area is dominated by three major sedimenthological formations such as the Patan Formation, the Thimi Formation and the Lower Terrace deposit [34] 
(Fig 1). The Thimi Formation contains sand, silt, clay, peat and gravel composed of granite and gneiss derived from the Shivapuri Range. Similarly the Patan formation is composed of fluviolacustrine deposits containing sand, silt, clay and peat. The Lower Terrace deposit consist micaceous sand, pebbles and granules.

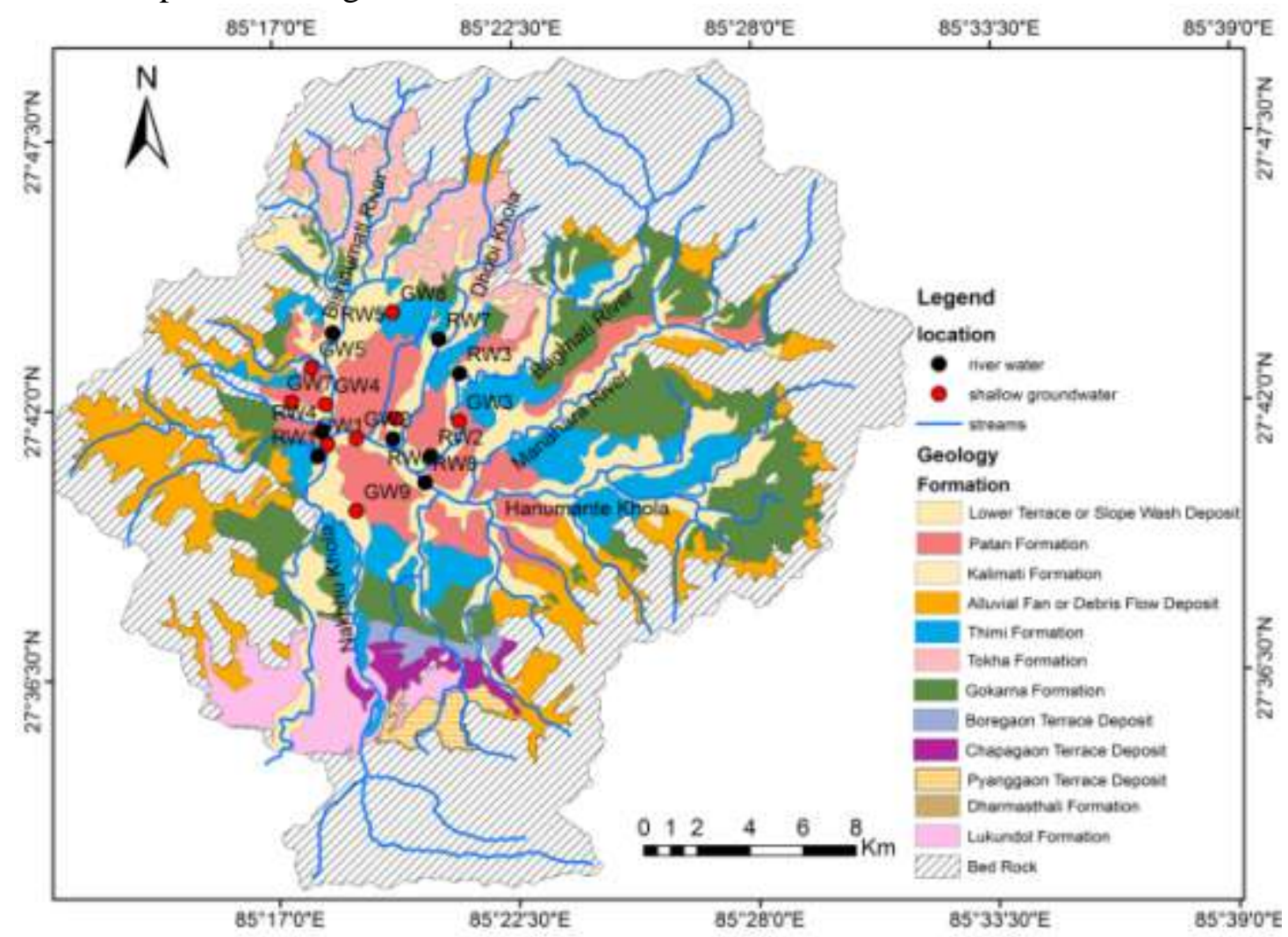

Fig 1: Sampling point on geological map of the Kathmandu Valley (compilation of Yoshida \& Igarashi, 1980, Sakai et al, 2008 and Dhital, 2015)

\section{METHODOLOGY}

Monthly collected samples from June 2010 to March 2011 of groundwater and river water by International Research Centre for River Basin Environment- University of Yamanashi (ICRE-UY), Japan was used for this research. These samples were stored in low temperatures at the lab of UY. Water samples were collected from 17 different locations among which 8 were from river and 9 from shallow groundwater (Fig 1 \& Table1). The river samples included the Bagmati River (RW1, RW2 \& RW3), the Bishnumati River (RW4 \& RW5), the Dhobi Khola (RW6 \& RW7) and the Manahara River (RW8). Similarly seven groundwater samples were taken from these river corridors ( 2 samples from 35 to $60 \mathrm{~m}$ and 4 samples from 90 to $200 \mathrm{~m}$ from the river channel) and three samples were collected far from the river channel. These samples were analyzed for chemical parameters and stable hydrogen and oxygen isotope in the laboratory of ICRE-UY, Japan.

In chemical analysis, concentration of major cation $\left(\mathrm{Ca}^{2+}, \mathrm{Mg}^{2+}, \mathrm{Na}^{+}, \mathrm{K}^{+}, \mathrm{NH}^{4}-\mathrm{N}\right)$ and anion $\left(\mathrm{SO}_{4}{ }^{2-}\right.$ $, \mathrm{Cl}^{-}, \mathrm{PO}^{4}-\mathrm{P}, \mathrm{NO}^{3}-\mathrm{N}$ ) were measured using ion chromatography (ICS-1100, Dionex, USA).

The stable isotope of hydrogen $(\delta \mathrm{D})$ and oxygen $\left(\delta^{18} \mathrm{O}\right)$ were analyzed using an isotope ratio mass spectrometer (IRMS) (Sercon, Hydra 20-20). The results were reported in per mill deviation with respect to VSMOW (Vienna Standard Mean Ocean Water) standards with precision $0.1 \%$ for $\delta^{18} \mathrm{O}$ and $1 \%$ for $\delta \mathrm{D}$. The isotopic ratios of hydrogen and oxygen are calculated by using the formula given by[35]:

Where $\mathrm{R}$ is defined as $\mathrm{D} / \mathrm{H}$ for $\delta \mathrm{D}$ and ${ }^{18} \mathrm{O} /{ }^{16} \mathrm{O}$ for $\delta^{18} \mathrm{O}$.

$$
\delta=\frac{\text { Rsample }-R V-S M O W}{R V-S M O W} \times 1000 \%
$$


Table1: Information on water sampling location

\begin{tabular}{|c|c|c|c|c|c|}
\hline Sample type & $\begin{array}{l}\text { Sample } \\
\text { ID }\end{array}$ & Latitude & Longitude & Elevation (m) & $\begin{array}{l}\text { Distance from river } \\
\text { (m) }\end{array}$ \\
\hline \multirow[t]{3}{*}{ River water } & RW1 & $27^{\circ} 41^{\prime 2} .1^{\prime \prime}$ & $85^{\circ} 17^{\prime} 58.25^{\prime \prime}$ & 1284 & \\
\hline & RW2 & $27^{\circ} 41^{\prime} 0.86^{\prime \prime}$ & $85^{\circ} 20^{\prime} 33.87^{\prime \prime}$ & 1293 & \\
\hline & RW3 & $27^{\circ} 42^{\prime} 41.99^{\prime \prime}$ & $85^{\circ} 21^{\prime} 14.39^{\prime \prime}$ & 1311 & \\
\hline \multirow[t]{3}{*}{ Groundwater } & GW1 & $27^{\circ} 41^{\prime} 16.4^{\prime \prime}$ & $85^{\circ} 18^{\prime} 11.6^{\prime \prime}$ & 1279 & 230 \\
\hline & GW2 & $27^{\circ} 41^{\prime 24.1 "}$ & $85^{\circ} 18^{\prime} 51.4^{\prime \prime}$ & 1285 & 60 \\
\hline & GW3 & $27^{\circ} 41^{\prime} 43.5^{\prime \prime}$ & $85^{\circ} 21^{\prime} 12.7^{\prime \prime}$ & 1312 & 218 \\
\hline \multirow[t]{2}{*}{ River water } & RW4 & $27^{\circ} 41^{\prime} 32.5^{\prime \prime}$ & $85^{\circ} 18^{\prime} 4.0^{\prime \prime}$ & 1287 & \\
\hline & RW5 & $27^{\circ} 43^{\prime} 32.69^{\prime \prime}$ & $85^{\circ} 18^{\prime} 20.21 "$ & 1303 & \\
\hline \multirow[t]{2}{*}{ Groundwater } & GW4 & $27^{\circ} 42^{\prime} 5.3^{\prime \prime}$ & $85^{\circ} 18^{\prime} 10.3^{\prime \prime}$ & 1281 & 40 \\
\hline & GW5 & $27^{\circ} 42^{\prime} 50.3^{\prime \prime}$ & $85^{\circ} 17^{\prime} 50.4^{\prime \prime}$ & 1305 & $\begin{array}{c}395(90 \mathrm{~m} \text { from } \\
\text { tributary) }\end{array}$ \\
\hline \multirow[t]{3}{*}{ River water } & RW6 & $27^{\circ} 41^{\prime} 22.37^{\prime \prime}$ & $85^{\circ} 19^{\prime} 41.84 "$ & 1292 & \\
\hline & RW7 & $27^{\circ} 43^{\prime} 23.96^{\prime \prime}$ & $85^{\circ} 20^{\prime} 46.32 "$ & 1311 & \\
\hline & GW6 & $27^{\circ} 41^{\prime} 47.4^{\prime \prime}$ & $85^{\circ} 19^{\prime} 45.9^{\prime \prime}$ & 1306 & 90 \\
\hline River water & RW8 & $27^{\circ} 40^{\prime} 28.75^{\prime \prime}$ & $85^{\circ} 20^{\prime} 25.46^{\prime \prime}$ & 1293 & \\
\hline \multirow[t]{3}{*}{ Groundwater } & GW7 & $27^{\circ} 42^{\prime} 8.6^{\prime \prime}$ & $85^{\circ} 17^{\prime} 22.8^{\prime \prime}$ & 1304 & 500 \\
\hline & GW8 & $27^{\circ} 43^{\prime} 57.5^{\prime \prime}$ & $85^{\circ} 19^{\prime} 43^{\prime \prime}$ & 1341 & 1720 \\
\hline & GW9 & $27^{\circ} 39^{\prime} 55^{\prime \prime}$ & $85^{\circ} 18 ' 50.2^{\prime \prime}$ & 1319 & 670 \\
\hline
\end{tabular}

\section{RESULTS}

\section{Chemical concentration of groundwater and river water}

The chemical parameters of groundwater and river water were summarized in Table 2 and Table 3 respectively. All chemical parameters in both water sources showed significant temporal as well as spatial variation.

\section{Chemical concentration of river water}

$\mathrm{Na}^{+}$and $\mathrm{Cl}^{-}$were dominant cation and anion in all river water. The mean value of $\mathrm{Na}^{+}$and $\mathrm{Cl}^{-}$in river water ranged from 11 to $88.9 \mathrm{mg} / \mathrm{l}$ and 8.2 to $87.1 \mathrm{mg} / \mathrm{l}$ respectively. The higher concentration was observed in downstream of the Bishnumati River (RW4) and the Dhobi Khola (RW6) where as lower value was obtained from the upstream of the Bagmati River (RW3). The concentration of other chemical ions such as $\mathrm{NH} 4-\mathrm{N}^{+}, \mathrm{K}^{+}, \mathrm{Mg}^{2+}$ and $\mathrm{SO} 4{ }^{2-}$ were also higher in these two downstream water samples (Table 2). The dominance of $\mathrm{Na}^{+}$together with $\mathrm{Cl}^{-}$in all downstream section of rivers reflects anthropogenic activities such as effluent from industrial wastes, solid wastes and human urine.

The ion concentration also shows distinct seasonal variation. Most chemical ions were higher in dry season (Dec-Jan) which was decreased to more than half in wet season (July-Sep). The minimum values indicate concentration of wet season whereas maximum was from dry season in Table 2 . Decreased in concentration of all chemical ions in wet season may be due to surface runoff through precipitation.

\section{Chemical concentration of groundwater}

The chemical concentration shows wide spatial variation in groundwater. Most of chemical ions were higher in such groundwater which was collected from nearby (35 to $250 \mathrm{~m}$ ) river channels as compared with those collected far from river channel (Table 3). As same as in river water, $\mathrm{Na}^{+}$and $\mathrm{Cl}^{-}$with additional as $\mathrm{SO} 4{ }^{2-}$ were dominant cation and anions in groundwater. Mean values of $\mathrm{Na}^{+}$ and $\mathrm{Cl}^{-}$ranged from 14.9 to $104 \mathrm{mg} / \mathrm{l}$ and 13.5 to $129.7 \mathrm{mg} / \mathrm{l}$ respectively whereas $\mathrm{SO}^{2-}$ mean value 
ranged from 11.5 to $174.2 \mathrm{mg} / \mathrm{l}$. Except GW8, all groundwater were collected from the Lower Terrace Deposit [34] (Fig 1) but have distinct variation in chemical ions indicate effects of human activities. The higher concentration of ions towards river channel as compared with those of far from river channel may also indicate higher anthropogenic activity near river corridor.

Value of $\mathrm{Mg}^{2+}$ and $\mathrm{K}^{+}$show least seasonal variation but $\mathrm{Na}^{+}, \mathrm{Ca}^{2+}, \mathrm{Cl}^{-}$and $\mathrm{SO}^{2-}$ show more fluctuation in groundwater. GW6 shows more or less similar values of all ions throughout the year but other all groundwater samples show seasonal variation.

\section{Isotopic composition}

\section{Isotope composition of River water}

The composition of $\delta^{18} \mathrm{O}$ and $\delta \mathrm{D}$ in water samples from four different rivers has least spatial variation (Fig 2). These values have similar trend of temporal variation throughout the collected months. Heavy isotopic concentration of $\delta^{18} \mathrm{O}$ and $\delta \mathrm{D}$ were observed in June 2010 ranging from 6.4 to $-7.7 \%$ and -43.3 to $52.9 \%$ respectively which was decreased in July and September $\left(\delta^{18} \mathrm{O}-\right.$ 8.1 to $-9.3 \%$ and $\delta \mathrm{D}-57.3$ to $-64.5 \%$ ) and then again slightly increased from November to March indicating wet seasons has lighter isotopic value (Fig 2).

Table 2: Chemical variation in river water

\begin{tabular}{|c|c|c|c|c|c|c|c|c|c|}
\hline \multirow{2}{*}{\multicolumn{2}{|c|}{$\begin{array}{c}\text { Parameters } \\
(\mathrm{mg} / \mathrm{l})\end{array}$}} & \multicolumn{3}{|c|}{ Bagmati River } & \multicolumn{2}{|c|}{ Bishnumati River } & \multicolumn{2}{|c|}{ Dhobi Khola } & \multirow{2}{*}{$\begin{array}{c}\text { Manahara } \\
\text { River } \\
\text { RW8 }\end{array}$} \\
\hline & & RW1 & RW2 & RW3 & RW4 & RW5 & RW6 & RW7 & \\
\hline \multirow{4}{*}{${ }^{+} \bar{z}$} & Min & 28.8 & 17.9 & 5.8 & 43.7 & 24.6 & 47.1 & 26.3 & 18.2 \\
\hline & $\operatorname{Max}$ & 107.3 & 87.4 & 16.5 & 136.6 & 74.9 & 101.2 & 111.5 & 60.3 \\
\hline & Average & 60.2 & 48.4 & 11.0 & 88.9 & 49.6 & 71.4 & 65.6 & 35.8 \\
\hline & SD & 24.9 & 23.4 & 3.8 & 31.1 & 16.5 & 18.1 & 28.7 & 14.5 \\
\hline \multirow{4}{*}{$\begin{array}{l}+7 \\
Z \\
1 \\
\mathbb{Z} \\
Z \\
Z\end{array}$} & Min & 3.3 & 2.4 & 0.6 & 4.0 & 2.2 & 5.7 & 2.5 & 1.8 \\
\hline & Max & 20.0 & 21.1 & 2.4 & 25.1 & 11.6 & 16.7 & 9.4 & 15.2 \\
\hline & Average & 9.7 & 9.2 & 1.2 & 13.4 & 6.5 & 11.5 & 5.5 & 5.7 \\
\hline & SD & 6.2 & 7.0 & 0.5 & 9.1 & 3.4 & 4.5 & 2.2 & 4.4 \\
\hline \multirow{4}{*}{ \pm} & Min & 7.8 & 4.6 & 1.5 & 11.1 & 6.7 & 13.5 & 6.3 & 4.4 \\
\hline & Max & 25.3 & 21.5 & 3.7 & 37.2 & 16.8 & 39.1 & 26.6 & 13.9 \\
\hline & Average & 14.9 & 12.1 & 2.6 & 22.7 & 12.5 & 22.0 & 14.9 & 8.7 \\
\hline & SD & 5.5 & 5.5 & 0.7 & 8.3 & 3.2 & 7.4 & 6.0 & 3.2 \\
\hline \multirow{4}{*}{$\stackrel{+}{+\infty}$} & Min & 4.3 & 2.5 & 1.4 & 5.4 & 4.8 & 5.9 & 4.2 & 5.1 \\
\hline & $\operatorname{Max}$ & 10.4 & 7.8 & 4.0 & 13.0 & 8.8 & 9.9 & 9.9 & 9.8 \\
\hline & Average & 7.1 & 5.1 & 2.6 & 8.9 & 6.8 & 7.6 & 6.9 & 6.9 \\
\hline & SD & 2.1 & 1.9 & 0.9 & 2.4 & 1.5 & 1.3 & 1.9 & 1.6 \\
\hline \multirow{4}{*}{$\stackrel{+}{\sim}$} & Min & 7.8 & 8.1 & 4.2 & 11.4 & 11.4 & 12.1 & 11.1 & 9.1 \\
\hline & Max & 26.6 & 20.0 & 10.1 & 28.5 & 32.1 & 24.8 & 21.2 & 29.2 \\
\hline & Average & 17.1 & 13.9 & 6.7 & 19.8 & 19.2 & 17.8 & 16.8 & 18.6 \\
\hline & SD & 5.9 & 4.5 & 1.8 & 5.9 & 6.6 & 3.4 & 3.5 & 5.9 \\
\hline \multirow{4}{*}{$\dot{U}$} & Min & 27.3 & 15.3 & 3.8 & 45.1 & 21.7 & 46.6 & 25.8 & 18.0 \\
\hline & Max & 101.5 & 87.8 & 13.6 & 141.6 & 72.3 & 102.5 & 98.9 & 58.1 \\
\hline & Average & 58.1 & 46.3 & 8.2 & 87.1 & 47.4 & 71.4 & 59.8 & 33.1 \\
\hline & SD & 24.2 & 24.0 & 3.2 & 31.2 & 16.1 & 17.2 & 24.9 & 13.8 \\
\hline
\end{tabular}


DOI : https://dx.doi.org/10.26808/rs.st.i8v3.04

International Journal of Advanced Scientific and Technical Research

Issue 8 volume 3 May-June 2018

Available online on http://www.rspublication.com/ijst/index.html

ISSN 2249-9954

\begin{tabular}{|c|c|c|c|c|c|c|c|c|c|}
\hline \multirow{4}{*}{$\begin{array}{l}z \\
\text { ô } \\
0 \\
z\end{array}$} & Min & 0.2 & 0.2 & 0.3 & 0.2 & 0.2 & 0.2 & 0.2 & 0.3 \\
\hline & Max & 0.2 & 0.4 & 0.8 & 0.3 & 0.5 & 0.3 & 0.9 & 0.6 \\
\hline & Average & 0.2 & 0.2 & 0.5 & 0.2 & 0.4 & 0.3 & 0.5 & 0.4 \\
\hline & SD & 0.0 & 0.1 & 0.1 & 0.0 & 0.1 & 0.0 & 0.3 & 0.1 \\
\hline \multirow{4}{*}{$\begin{array}{l}\dot{+} \\
\dot{0}\end{array}$} & Min & 0.8 & 0.8 & 0.4 & 3.8 & 0.8 & 4.3 & 2.8 & 1.0 \\
\hline & Max & 9.8 & 9.7 & 2.1 & 10.6 & 9.1 & 11.3 & 10.4 & 9.1 \\
\hline & Average & 5.5 & 5.4 & 1.3 & 7.5 & 4.6 & 8.8 & 6.9 & 3.0 \\
\hline & SD & 3.0 & 3.3 & 0.8 & 2.4 & 3.0 & 2.1 & 2.8 & 2.5 \\
\hline \multirow{4}{*}{ İ } & Min & 2.7 & 7.1 & 3.6 & 0.9 & 1.5 & 1.9 & 6.2 & 9.7 \\
\hline & Max & 25.4 & 26.5 & 9.9 & 33.4 & 25.0 & 28.3 & 37.0 & 21.4 \\
\hline & Average & 15.6 & 15.7 & 6.2 & 20.4 & 16.2 & 18.4 & 21.5 & 14.7 \\
\hline & SD & 6.6 & 6.6 & 1.9 & 9.0 & 6.6 & 6.8 & 9.7 & 3.4 \\
\hline
\end{tabular}

Table 3: Chemical variation in groundwater

\begin{tabular}{|c|c|c|c|c|c|c|c|c|c|c|}
\hline \multirow{2}{*}{\multicolumn{2}{|c|}{$\begin{array}{c}\text { Parameters } \\
(\mathrm{mg} / \mathrm{l})\end{array}$}} & \multicolumn{3}{|c|}{ Along Bagmati River } & \multicolumn{2}{|c|}{ Along Bishnumati } & \multirow{2}{*}{$\begin{array}{c}\text { Along Dhobi } \\
\text { GW6 }\end{array}$} & \multicolumn{3}{|c|}{ Away from river } \\
\hline & & GW1 & GW2 & GW3 & GW4 & GW5 & & GW7 & GW8 & GW9 \\
\hline \multirow{4}{*}{$+\sqrt{\pi}$} & Min & 32.4 & 49.6 & 42.9 & 72.6 & 55.2 & 34.0 & 14.0 & 12.1 & 5.9 \\
\hline & $\operatorname{Max}$ & 41.2 & 187.5 & 86.2 & 101.1 & 123.8 & 36.1 & 35.7 & 17.9 & 38.2 \\
\hline & Average & 35.7 & 104.0 & 71.9 & 85.4 & 83.8 & 35.2 & 24.5 & 14.9 & 18.8 \\
\hline & $\mathrm{SD}$ & 3.2 & 43.5 & 12.6 & 8.9 & 18.9 & 0.7 & 8.9 & 1.6 & 10.3 \\
\hline \multirow{4}{*}{ 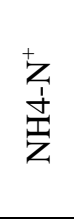 } & Min & 3.5 & 0.0 & 6.6 & 2.2 & 7.2 & 2.5 & 4.0 & 0.7 & 1.2 \\
\hline & Max & 5.8 & 0.0 & 9.7 & 4.7 & 9.1 & 2.8 & 12.5 & 0.7 & 4.2 \\
\hline & Average & 4.5 & 0.0 & 8.6 & 3.4 & 8.2 & 2.6 & 6.8 & 0.7 & 2.3 \\
\hline & $\mathrm{SD}$ & 0.8 & 0.0 & 1.1 & 0.9 & 0.8 & 0.1 & 3.1 & 0.0 & 0.9 \\
\hline \multirow{4}{*}{ \pm} & Min & 3.7 & 12.8 & 9.6 & 46.1 & 12.0 & 7.7 & 4.0 & 1.4 & 2.0 \\
\hline & $\operatorname{Max}$ & 4.7 & 22.6 & 17.0 & 52.2 & 25.9 & 8.2 & 6.0 & 2.3 & 19.8 \\
\hline & Average & 4.2 & 18.1 & 15.1 & 49.4 & 20.0 & 7.9 & 5.0 & 1.8 & 8.2 \\
\hline & SD & 0.3 & 2.7 & 2.3 & 2.0 & 5.0 & 0.1 & 0.6 & 0.2 & 6.2 \\
\hline \multirow{4}{*}{$\sum^{+\infty}$} & Min & 24.4 & 15.7 & 5.8 & 17.6 & 23.3 & 9.6 & 17.4 & 14.4 & 4.1 \\
\hline & $\operatorname{Max}$ & 31.9 & 30.8 & 8.9 & 23.8 & 30.8 & 10.8 & 21.3 & 17.3 & 11.7 \\
\hline & Average & 28.3 & 22.1 & 7.5 & 20.7 & 27.3 & 10.1 & 19.3 & 15.9 & 6.7 \\
\hline & SD & 2.5 & 4.6 & 0.8 & 2.1 & 2.6 & 0.3 & 1.2 & 1.0 & 2.6 \\
\hline \multirow{4}{*}{ Uే } & Min & 19.4 & 27.0 & 6.2 & 18.1 & 6.1 & 9.4 & 6.6 & 7.2 & 12.1 \\
\hline & Max & 51.5 & 61.3 & 13.1 & 32.8 & 72.5 & 18.2 & 20.3 & 23.7 & 48.7 \\
\hline & Average & 36.0 & 40.5 & 9.8 & 24.3 & 38.0 & 13.7 & 12.1 & 13.5 & 26.0 \\
\hline & $\mathrm{SD}$ & 10.3 & 10.8 & 2.3 & 4.2 & 21.5 & 2.7 & 3.9 & 5.1 & 10.3 \\
\hline \multirow{4}{*}{$\dot{U}$} & Min & 38.6 & 66.6 & 31.0 & 101.3 & 122.9 & 45.1 & 30.9 & 7.2 & 17.2 \\
\hline & Max & 50.5 & 183.8 & 60.0 & 142.2 & 174.0 & 48.4 & 50.1 & 23.7 & 79.3 \\
\hline & Average & 43.5 & 129.7 & 50.3 & 123.5 & 145.4 & 47.0 & 40.4 & 13.5 & 45.5 \\
\hline & SD & 4.5 & 43.2 & 8.3 & 14.9 & 17.9 & 1.0 & 7.0 & 5.1 & 20.2 \\
\hline \multirow{2}{*}{$\overbrace{z}^{\prime} z$} & Min & 0.3 & 2.2 & 9.0 & 10.3 & 0.2 & 0.0 & 0.2 & 1.9 & 0.3 \\
\hline & Max & 0.3 & 20.5 & 21.7 & 26.2 & 1.8 & 0.0 & 3.4 & 2.4 & 1.5 \\
\hline
\end{tabular}




\begin{tabular}{|c|c|c|c|c|c|c|c|c|c|c|}
\hline & Average & 0.3 & 8.9 & 13.8 & 15.0 & 0.8 & 0.0 & 1.5 & 2.2 & 0.8 \\
\hline & SD & 0.0 & 5.2 & 5.0 & 5.0 & 0.6 & 0.0 & 1.2 & 0.6 & 0.4 \\
\hline \multirow{4}{*}{$\begin{array}{l}\frac{1}{1} \\
\dot{1} \\
0\end{array}$} & Min & 0.0 & 2.1 & 0.0 & 1.0 & 0.0 & 0.0 & 0.5 & 0.0 & 0.6 \\
\hline & Max & 0.0 & 2.1 & 0.0 & 4.0 & 0.0 & 0.0 & 0.5 & 0.0 & 2.0 \\
\hline & Average & 0.0 & 2.1 & 0.0 & 2.5 & 0.0 & 0.0 & 0.5 & 0.0 & 1.3 \\
\hline & SD & 0.0 & 0.0 & 0.0 & 1.2 & 0.0 & 0.0 & 0.0 & 0.0 & 0.7 \\
\hline \multirow{4}{*}{ 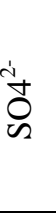 } & Min & 118.5 & 80.3 & 31.6 & 51.2 & 24.7 & 24.6 & 0.9 & 13.8 & 5.1 \\
\hline & Max & 238.4 & 135.0 & 49.1 & 73.0 & 212.4 & 28.5 & 26.8 & 16.8 & 126.2 \\
\hline & Average & 174.2 & 99.3 & 42.0 & 61.1 & 134.3 & 26.5 & 11.5 & 15.3 & 40.7 \\
\hline & SD & 36.1 & 17.5 & 5.1 & 6.7 & 61.2 & 1.4 & 11.2 & 1.3 & 37.2 \\
\hline
\end{tabular}

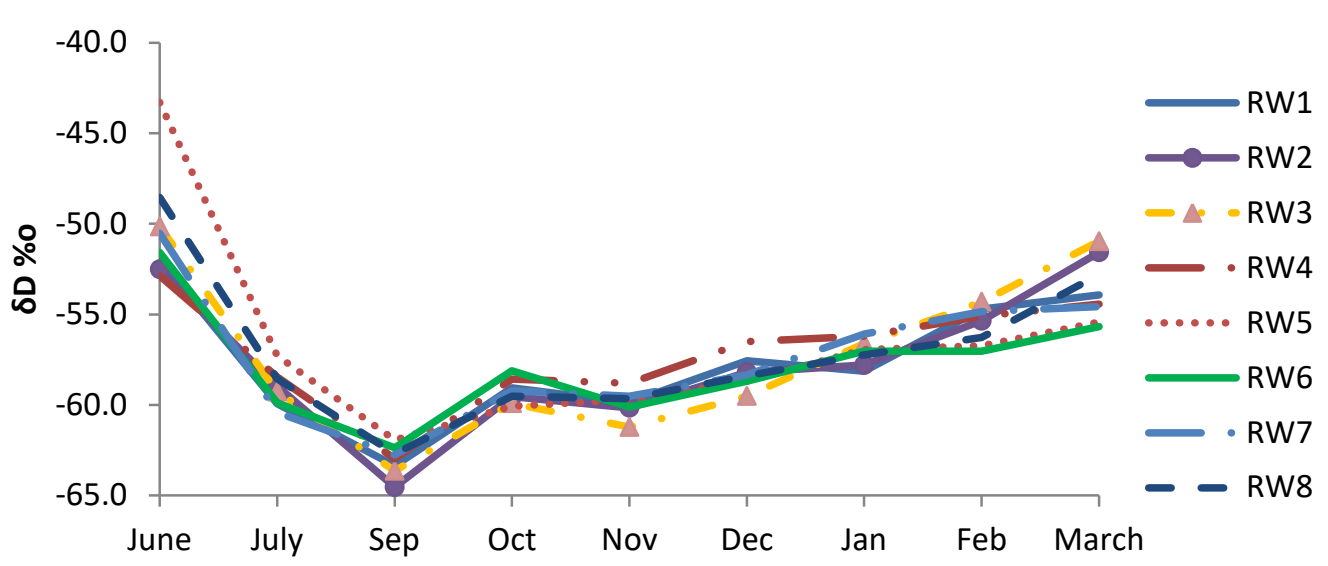

Fig. 2: Temporal and spatial variation of $\delta \mathrm{D}$ in river water $(\mathrm{RW})$

\section{Isotopic composition of groundwater}

The isotopic composition of groundwater near to river and far from river channel was very different. The $\delta^{18} \mathrm{O}$ and $\delta \mathrm{D}$ values of groundwater was not much temporally variable except in GW2, GW4 and GW5 (Fig 3). GW2 has lighter isotopic value in September to November. The maximum value of variation was $1.7 \%$ in $\delta^{18} \mathrm{O}$ and $14.2 \%$ in $\delta \mathrm{D}$. Except in GW8 and GW9, other groundwater has similar values of $\delta^{18} \mathrm{O}(-7.8$ to $-8.1 \%$ ) and $\delta \mathrm{D}(-53.5$ to $55.4 \%$. The GW8 shows heavier isotopic composition as $\delta^{18} \mathrm{O}$ is $-7.1 \%$ and $\delta \mathrm{D}$ is $-47.6 \%$ where as GW9 has least $\delta^{18} \mathrm{O}(-$ $9.0 \%$ ) and $\delta \mathrm{D}(-63.5 \%)$. These two groundwater were collected away from river channel have significant isotopic variation.

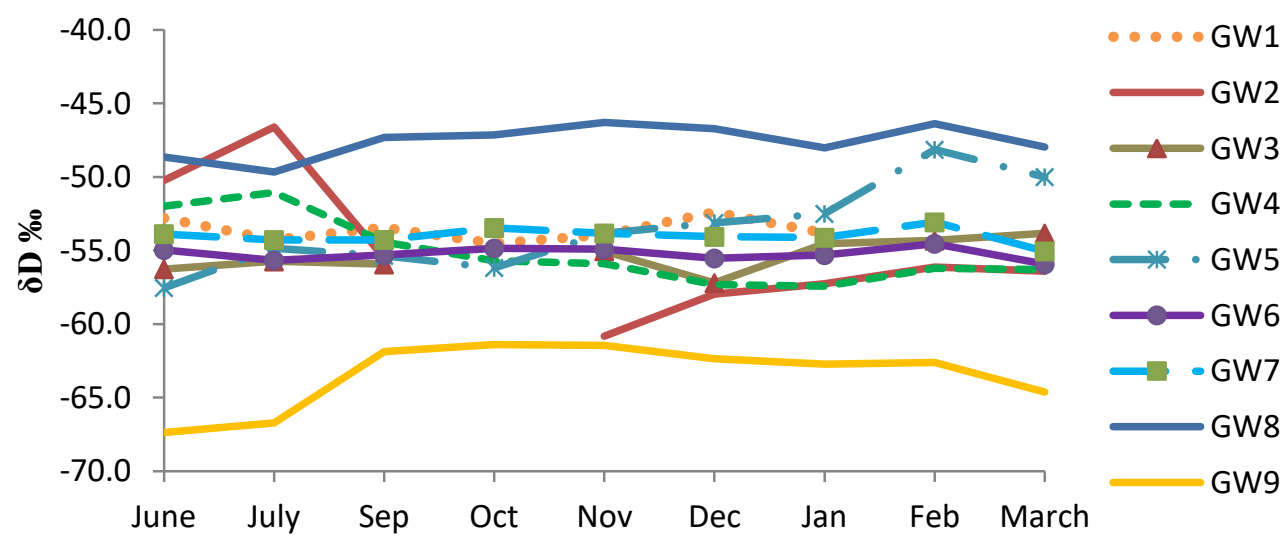

Fig. 3: Temporal and spatial variation of $\delta \mathrm{D}$ in groundwater $(\mathrm{GW})$ 


\section{Comparison of isotopes in river water and groundwater}

The relation between $\delta^{18} \mathrm{O}$ and $\delta \mathrm{D}$ of river water and groundwater for dry and wet season were presented in Fig 4 with GMWL. Except GW8 and GW9, all groundwater isotopic values were overlapped with river water samples in dry season. Groundwater which showed similar isotopic values with river samples were collected from nearby river channel (within $200 \mathrm{~m}$ ) and remaining two which has different isotopic value was located far away from river channel (500 and $1500 \mathrm{~m}$ ). This plot indicates that there is most probability of interaction between river water and groundwater which was located nearby river channel.

But in the case of wet season, the isotopic composition of river water was slightly lighter than dry season but groundwater has similar isotopic composition as in dry season. The lighter isotopic value of river water may be resulted by addition of surface runoff through precipitation as rainfall has lighter isotopic value [36][37][38]. As all water samples are closer to GMWL (Global Meteoric Water Line), there is less chances of evaporation in both seasons. Previous report also finds that Kathmandu Valley rivers have no evidence of evaporation [36].

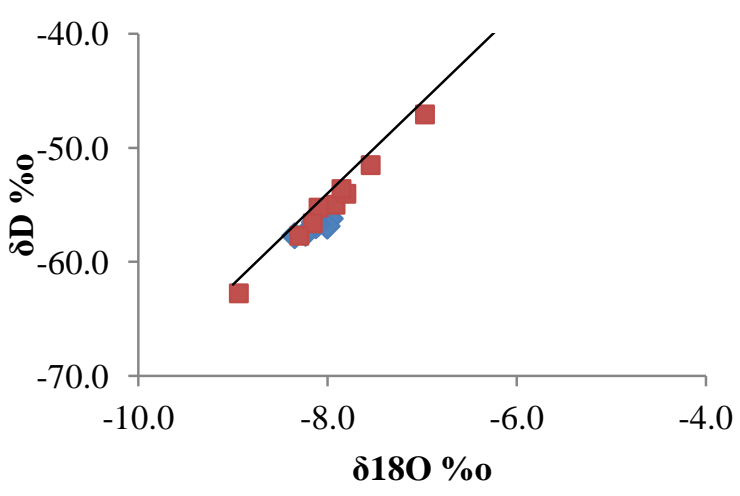

(a)

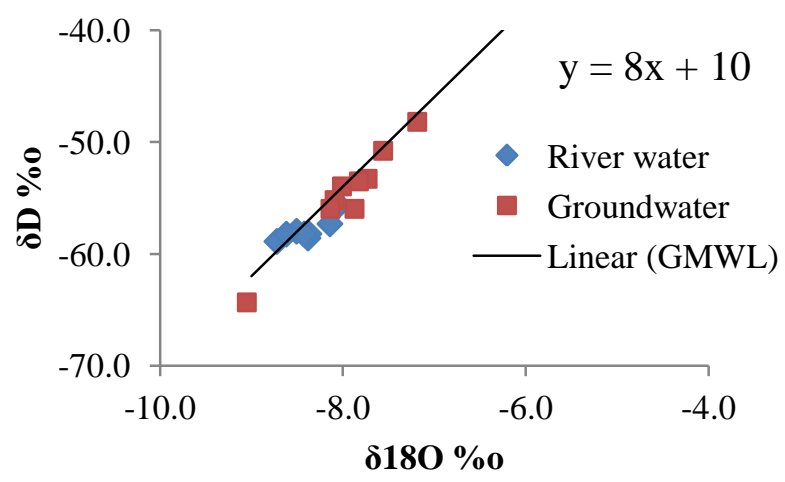

(b)

Fig 4: Plot of $\delta^{18} \mathrm{O}$ and $\delta \mathrm{D}$ for groundwater and river water a) dry season and b) wet season

\section{DISCUSSION}

\section{Interconnection between river water and groundwater}

River water from the Bagmati, Bishnumati and Dhobi Khola with groundwater nearby these rivers was used to identify interconnection of groundwater and river water. One sample from the Manahara River and three samples from groundwater (away from river channel) were excluded for this.

\section{Bagmati river corridor}

The values of $\delta^{18} \mathrm{O}, \delta \mathrm{D}, \mathrm{Na}$ and $\mathrm{Cl}$ were plotted against month from river water (RW1, RW2 and RW3) and groundwater (GW1, GW2 and GW3) for comparison of river and groundwater (Fig 5 \& 6). The plots against $\delta^{18} \mathrm{O}$ and $\delta \mathrm{D}$ verses months clearly show that the isotopic composition is only similar in dry season in GW1 and GW3 and has heavy isotope in wet season as compared with river isotope. But in the case of GW2, the wet season has also somehow similar trend of decreasing value as in river water. Similarly in the plot of $\mathrm{Na}^{+}$and $\mathrm{Cl}^{-}, \mathrm{GW} 1$ and GW3 do not show seasonal variation but in the case of GW2, it shows significant variation with months. Based on these isotopic and chemical parameters $\left(\mathrm{Na}^{+}\right.$and $\left.\mathrm{Cl}^{-}\right)$, it can be said that the groundwater can discharge to the river water during dry season but the chances of groundwater recharge from river water and rainfall infiltration is very low in GW1 and GW3 [11]. But in the case of GW2, there is possibility of recharge from river water. 


\section{Bishnumati River Corridor}

As same in the Bagmati River, plots of $\delta^{18} \mathrm{O}, \delta \mathrm{D}, \mathrm{Na}^{+}$and $\mathrm{Cl}^{-}$verses months were used to compare river water (RW4 \& RW5) and groundwater (GW4 \& GW5) (Fig 5 \& 6). GW5 shows different isotopic data as well as chemical ions as compared with river water which may indicate less probability of interaction. But in the case of GW4, it has similar isotopic composition as in RW5 in dry season (Dec-March) and also has same decreasing value trend in September. $\mathrm{Na}^{+}$and $\mathrm{Cl}^{-}$were also diluted in wet season. Dilution in ions and similar isotopic value trend in GW4 indicate the possibility of recharge of groundwater from river water.
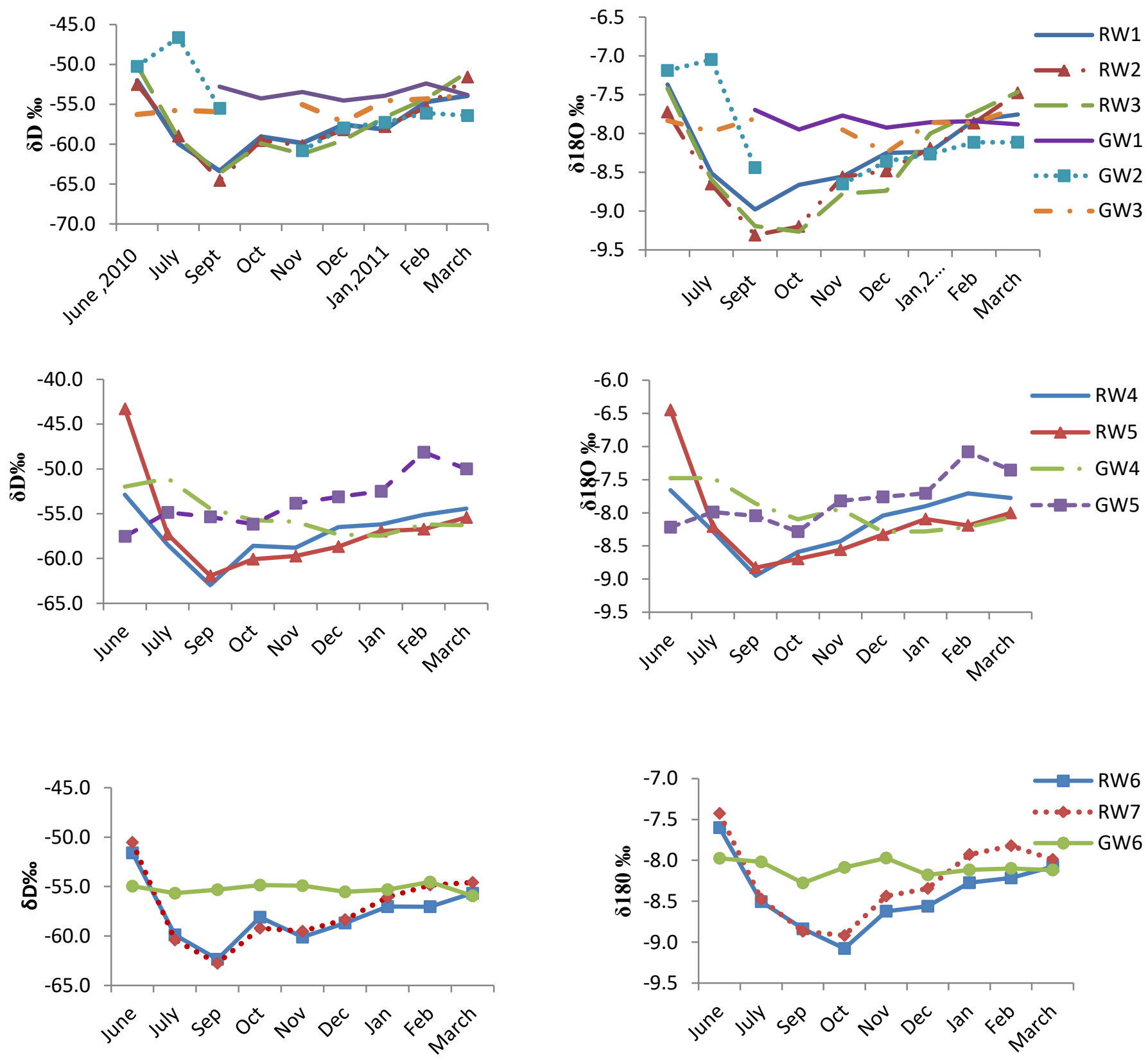

Fig 5: $\delta^{18} \mathrm{O}$ and $\delta \mathrm{D}$ verses month plots of the Bagmati River, the Bishnumati River and the Dhobi Khola 


\section{Dhobi Khola Corridor}

The uniform isotopic composition and constant chemical concentration $\left(\mathrm{Na}^{+}\right.$and $\left.\mathrm{Cl}^{-}\right)$in $\mathrm{GW} 6$ show that the absence of chances of recharge of groundwater from river water. But the similar isotopic composition in dry season reveals the possibility of recharge of river water from groundwater (Fig 5 \& 6).
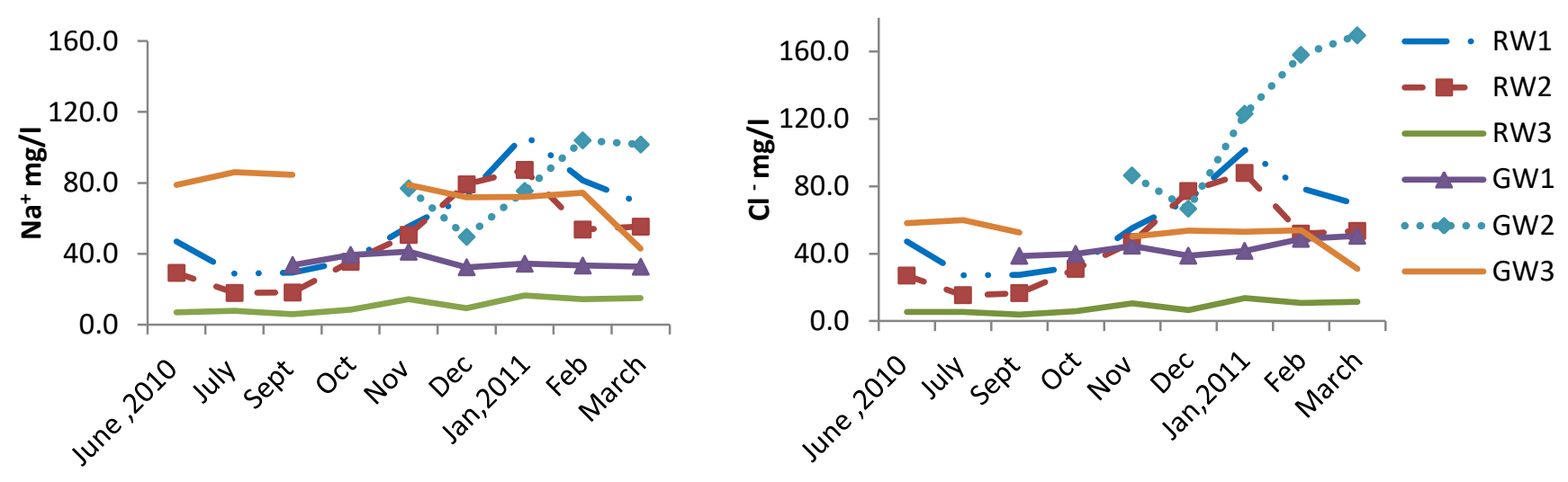

a)
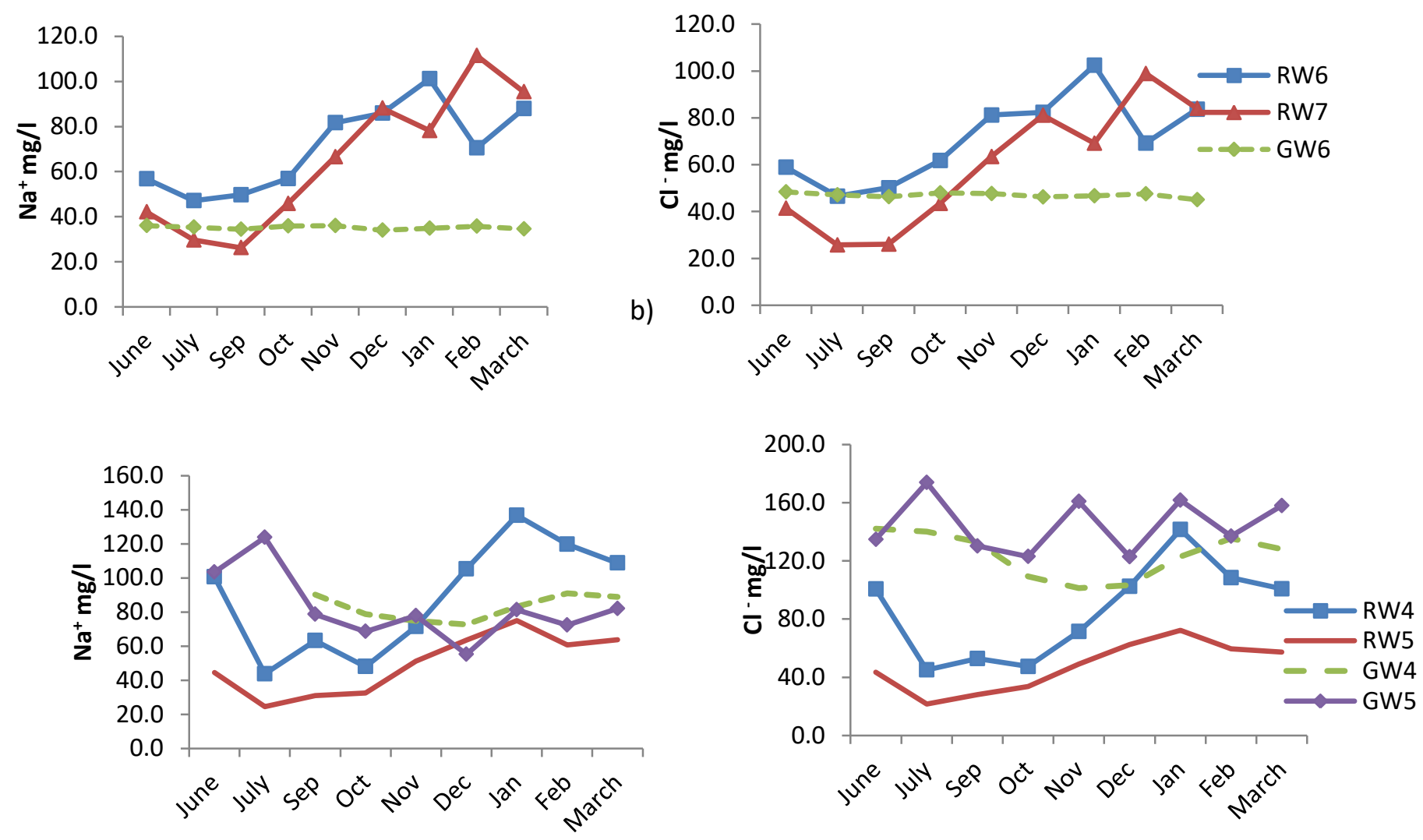

c)

Fig 6: $\mathrm{Na}^{+}$and $\mathrm{Cl}^{-}$verses month plots of a) the Bagmati River, b) the Bishnumati River and c) the Dhobi Khola 


\section{CONCLUSIONS}

The present research is basically focused on study of chemical parameter and stable water isotopes of river water and groundwater (nearby river channel) of the Kathmandu Valley. Chemical analysis of water of river gives the information that all the major rivers of the valley are deteriorating towards downstream possibly by anthropogenic activities. Concentration of chemical ions is decreased nearly to half from dry season to wet season. Isotope of all rivers has similar variation trend indicating similar type of recharge source.

Groundwater near to river channel (within $200 \mathrm{~m}$ ) has higher chemical concentration as compared with those which located far away from river channel (greater than $500 \mathrm{~m}$ ). The relation of $\delta^{18} \mathrm{O}$ and $\delta \mathrm{D}$ also shows cluster of river water and groundwater (near to river) in dry season. Similarity of isotopic data in GW1, GW3, GW6 (90 to $230 \mathrm{~m}$ ) river water in dry season conform that the groundwater recharges river. But in the case of GW2 and GW4 (35 to $60 \mathrm{~m}$ ), isotopic value was decreased in September as in river water indicating probability of recharge from river through bank infiltration.

In overall condition, there exist interaction between river water and that groundwater which is near to river channel but the condition of recharge and discharge to river water from groundwater or vice-versa is changed in location. Thus the interconnectivity not only can change water quantity but also on quality of both water systems. In present research, fewer water samples were used to analyze chemical and environmental isotope; it has lack of data on water table depth of wells, subsurface lithology and these layer inclination. Thus for further detail study of interaction, it need larger number of water samples from river as well as from groundwater with detail subsurface lithology, water table depth of wells, elevation of water level in river with river sediments which will help to verify chemical and isotopic analysis.

\section{ACKNOWLEDGEMENTS}

The authors are grateful to International Research Centre for River Basin Environment- University of Yamanashi (ICRE-UY), Japan for providing water samples and lab facilities.

\section{REFERENCES}

I.S. Lamontagne, A. Taylor, P. G. Cook, and A. Smithson, "Interconnection of surface and groundwater systems - River losses from losing/disconnected streams: Namoi River site report," no. May, 2011.

II.E. Kalbus, F. Reinstorf, and M. Schirmer, "Measuring methods for groundwater - surface water interactions: a review," Hydrol. Earth Syst. Sci, vol. 10, pp. 873-887, 2006.

III.S. Wilhelm and B. F. Mountains, "Application of electrical resistivity tomography ( ERT ) together with tracer data to identify hydrological process areas at a surface water / groundwater test site," 2004.

IV.S. B. Meyerhoff, R. M. Maxwell, A. Revil, J. B. Martin, M. Karaoulis, and W. D. Graham, "Characterization of groundwater and surface water mixing in a semiconfined karst aquifer using time-lapse electrical resistivity tomography," Water Resour. Res., vol. 50, no. 3, pp. 2566-2585, 2014.

V.P. J. McLachlan, J. E. Chambers, S. S. Uhlemann, and A. Binley, "Geophysical characterisation of the groundwater-surface water interface," Adv. Water Resour., vol. 109, pp. 302-319, 2017.

VI.J. . Terwey, "Isotopes in Groundwater Hydrology," in Isotope Tracers in Catchment Hydrology, no. 144, Elsevier, 1998, pp. 203-246.

VII.J. Katz, Brian. Coplen, Tyler. Bullen, T. Hal Davis, "Use of Chemical and Isotopic Tracers to Characterize the Interations Between Ground Water and Surface Water in Mantled Karst," Ground Water, vol. 35, no. 6, pp. 1014-1028, 1997.

VIII.M.A. Awad, N.E.EI Arabi and M.S Hazma, "Use of Solute chemistry and isotope to identify 
sources of groundwater recharge in the Nile aquifer system, Upper Egypt," Ground Water, vol. 35, no. 2, pp. 223-228,1997.

IX.R. J. Hunt, T. B. Coplen, N. L. Haas, D. A. Saad, and M. A. Borchardt, "Investigating surface water-well interaction using stable isotope ratios of water," J. Hydrol., vol. 302, no. 1-4, pp. $154-172,2005$.

X.X. Song, X. Liu, J. Xia, J. Yu, and C. Tang, "A study of interaction between surface water and groundwater using environmental isotope in Huaisha River basin," Sci. China, Ser. D Earth Sci., vol. 49, no. 12, pp. 1299-1310, 2006.

XI.L. Yang, X. Song, Y. Zhang, D. Han, B. Zhang, and D. Long, "Characterizing interactions between surface water and groundwater in the Jialu River basin using major ion chemistry and stable isotopes," Hydrol. Earth Syst. Sci., vol. 16, no. 11, pp. 4265-4277, 2012.

XII.G. Singh, D. D. Singh, and P. S. K. Sharma, " Effect of polluted surface water on groundwater: A case studyof Budha Nullah ,"' IOSR J. Mech. Chem. Eng., vol. 5, no. 5, pp. $1-8,2013$.

XIII.R. Malla, S. Shrestha, S. K. Chapagain, and M. Shakya, "Physico-chemical and oxygenhydrogen isotopic assessment of Bagmati and Bishnumati Rivers and the shallow groundwater along the river corridors,'Journal of Water Resource and Protection, vol. 7, pp. 1435-1448, 2015.

XIV.A. Brenot, E. Petelet-Giraud, and L. Gourcy, "Insight from surface water-groundwater interactions in an alluvial aquifer: Contributions of $\delta 2 \mathrm{H}$ and $\delta 18 \mathrm{O}$ of water, $\delta 34 \mathrm{SSO} 4$ and $\delta 180 S O 4$ of sulfates, 87Sr/86Sr Ratio," Procedia Earth Planet. Sci., vol. 13, pp. 84-87, 2015.

XV.K. K. Ali and A. R. Ajeena, "Assessment of interconnection between surface water and groundwater in Sawa Lake area, southern Iraq, using stable isotope technique," Arab. J. Geosci., vol. 9, no. 14, 2016.

XVI.X. Li, C. Tang, Z. Han, and Y. Cao, "Hydrochemical characteristic and interaction process of surface and groundwater in mid-lower reach of Hanjiang River, China," Environ. Earth Sci., vol. 75 , no. 5, pp. 1-12, 2016.

XVII.B. Zhang, X. Song, Y. Zhang, Y. Ma, C. Tang, L. Yang, and Z.-L. Wang, "The interaction between surface water and groundwater and its effect on water quality in the Second Songhua River basin, northeast China,” J. Earth Syst. Sci., vol. 125, no. 7, pp. 1495-1507, 2016.

XVIII.L. Zhan, J. Chen, S. Zhang, L. Li, D. Huang, and T. Wang, "Isotopic signatures of precipitation, surface water, and groundwater interactions, Poyang Lake Basin, China," Environ. Earth Sci., vol. 75, no. 19, pp. 1-14, 2016.

XIX.T. Nakamura, K. Nishida, and F. Kazama, "Influence of a dual monsoon system and two sources of groundwater recharge on Kofu basin alluvial fans, Japan," Hydrol. Res., vol. 48, no. 4, pp. 1-17, 2017.

XX.N. R. Warner, J. Levy, K. Harpp, and F. Farruggia, "Drinking water quality in Nepal's Kathmandu Valley: A survey and assessment of selected controlling site characteristics," Hydrogeol. J., vol. 16, no. 2, pp. 321-334, 2008.

XXI.T. Prasai, B. Lekhak, D. R. Joshi, and M. P. Baral, "Microbiological analysis of drinking water of Kathmandu Valley," Sci. World, vol. 5, no. 5, pp. 112-114, 2010.

XXII.J. Diwakar, K. D. Yami, and T. Prasai, "Assessment of drinking water of Bhaktapur Municipality Area in Pre-Monsoon Season," Sci. World, vol. 6, no. 6, pp. 94-98, 2010.

XXIII.B. R. Pant, "Ground water quality in the Kathmandu valley of Nepal," Environ. Monit. Assess., vol. 178, no. 1-4, pp. 477-485, 2011.

XXIV.D. R. Pathak, R. Yatabe, N. P. Bhandary, and E. Study, "Statistical analysis of factors affecting groundwater quality in shallow aquifer of Kathmandu, Nepal," International Journal of Water Research, vol. 1, no. 1, pp. 12-20, 2013.

XXV.C. Tamrakar and P. Shakya, "Physico-chemical assessment of deep groundwater quality 
ofvarious sites of Kathmandu Metropolitan City , Nepal,” Res. J. Chem. Sci., vol. 3, no. 8, pp. 78-82, 2013.

XXVI.A. Bittner, "Nepal Drinking Water Quality Assessment : Nitrates and Ammonia," Thesis of master degree submitted at the Massachusetts Institute of Technology, pp. 1-70, 2000.

XXVII.D. C. Devkota and K. Watanabe, "Impact of solid waste on water quality of Bishnumati River and,” J. Nepal Geol. Soc., vol. 31, no. Karki 2002, pp. 19-24, 2006.

XXVIII.R. Bajracharya and N. K. Tamrakar, "Environmental status of Manahara River, Kathmandu , Nepal,” Bull. Dep. Geogr., pp. 21-32, 2007.

XXIX.O. Moog, and S. Sharma, "Biological rapid field assessment of water quality in the Bagmati River and its tributaries, Kathmandu Valley, Nepal," International Conference on Ecology of High Mountain Areas- Water quality and Limnological issue, pp. 609-621,2005.

XXX.S. Pandey, "Water pollution and health.," Kathmandu Univ. Med. J. (KUMJ), vol. 4, no. 1, pp. 128-34, 2006.

XXXI.R. Gautam, J. K. Shrestha, G. Kumar, and C. Shrestha, "Assessment of river water intrusion at the periphery of Bagmati River in Kathmandu Valley," Nepal J. Sci. Technol., vol. 14, no. 1, pp. 137-146, 2013.

XXXII.J. Stocklin, "Geology of Nepal and its regional frame", Journal of Geological SocietyLondon, vol. 137, pp. 1-34, 1980.

XXXIII.M.Yoshida, and Y. Igarashi, "Neogene to quaternary lacustrine sediment in the Kathmandu Valley, Nepal," Jour. Nepal Geological Society, Special issue, vol. 4, pp.37-100, 1984.

XXXIV.T. Sakai, A. P. Gajurel, H. Tabata, N. Ooi, T. Takagawa, H. Kitagawa, and B. N. Upreti, "Revised lithostratigraphy of fluvio-lacustrine sediments comprising northern Kathmandu basin in central Nepal," J. Nepal Geol. Soc., vol. 37, no. 2001, pp. 25-44, 2008.

XXXV.H. Craig, "Isotopic Variations in Meteoric Waters," Science (80-. )., vol. 133, no. 3465, pp. 1702-1703, 1961.

XXXVI.A. P. Gajurel, C. France-Lanord, P. Huyghe, C. Guilmette, and D. Gurung, "C and O isotope compositions of modern fresh-water mollusc shells and river waters from the Himalaya and Ganga plain," Chem. Geol., vol. 233, no. 1-2, pp. 156-183, 2006.

XXXVII.M. Tsujimura, Y. Abe, T. Tanaka, J. Shimada, S. Higuchi, T. Yamanaka, G. Davaa, and D. Oyunbaatar, "Stable isotopic and geochemical characteristics of groundwater in Kherlen River basin, a semi-arid region in eastern Mongolia," J. Hydrol., vol. 333, no. 1, pp. 47-57, Jan. 2007.

XXXVIII.M. S. Lachniet and W. P. Patterson, "Oxygen isotope values of precipitation and surface waters in northern Central America (Belize and Guatemala) are dominated by temperature and amount effects," Earth Planet. Sci. Lett., vol. 284, no. 3-4, pp. 435-446, Jul. 2009. 